\title{
First cardiovascular event in patients with type 2 diabetes mellitus of a cardiovascular risk management program of a poor Colombian population: a cohort study
}

Pablo Miranda-Machado ${ }^{*}$, Fernando Salcedo-Mejía ${ }^{1} \mathbb{0}$, Justo Paz Wilches², Juan Fernandez-Mercado², Fernando De la Hoz-Restrepo ${ }^{3}$ and Nelson Alvis-Guzmán ${ }^{4}$

\begin{abstract}
Background: According to several studies in population of high-income countries (HIC), patients with Type 2 diabetes mellitus (DM) have a considerably higher risk of cardiovascular morbidity and mortality. However, it is not clear if the magnitude of this association can be widespread in other populations. The objective of this study was to determine the independent association between Type $2 \mathrm{DM}$ and first cardiovascular event in Colombian Caribbean poor population with no records of previous cardiovascular events reported.

Methods: We retrospectively reviewed the individual records from the hospitalizations database of 64,668 patients of cardiovascular risk management program from July 2014 to December 2015. We used a propensity score matching cohort analysis for this study. The Kaplan-Meier curves were constructed for the cardiovascular events related endpoints and matched Cox-regression analysis to estimate associations of a history of Type 2 DM with cardiovascular outcomes during 1.5 years of follow-up. A formal sensitivity analysis using The Breslow-Day and Tarone Homogeneity tests was conducted.
\end{abstract}

Results: Out of 56,351 patients with no previous cardiovascular events records, 19,368 (34.4\%) patients were found to suffer Type 2 DM. Using propensity scores for Type 2 DM, we gathered a cohort of 18,449 pairs of patients with and without Type 2 DM who were balanced on 22 baseline characteristics. A first cardiovascular event occurred in $650(3.5 \%)$ and 403 (2.1\%) matched patients with and without Type 2 DM, respectively, during 1.5 years of followup. Type 2 DM was associated with first cardiovascular event (HR 1.69; 95\% Cl 1.43-2.00; $p=0.000$ ), AMI (HR 1.79; 95\% Cl 1.45-2.20; $p=0.000)$ and stroke (HR 1.54; 95\% Cl 1.18-2.02; $p=0.001)$. Hazard ratios (95\% Cls) for the association of Type $2 \mathrm{DM}$ with all-cause mortality, cardiovascular mortality and all-cause hospitalization were $1.36(1.21-1.53 ; p<0.001), 1.52(1.12-2.08 ; p 0.004)$, and $1.20(1.21-1.53 ; p<0.001)$, respectively.

Conclusion: Type 2 DM resulted to be a significant independent risk factor for first cardiovascular event in Colombian Caribbean poor population with no previous records of cardiovascular events.

Keywords: Cardiovascular outcomes, Diabetes, Poor population

* Correspondence: mmpa9@hotmail.com

${ }^{1}$ ALZAK Foundation, 130002, Crespo 70 \#6-99, Cartagena, Colombia

Full list of author information is available at the end of the article

(c) The Author(s). 2019 Open Access This article is distributed under the terms of the Creative Commons Attribution 4.0 International License (http://creativecommons.org/licenses/by/4.0/), which permits unrestricted use, distribution, and reproduction in any medium, provided you give appropriate credit to the original author(s) and the source, provide a link to the Creative Commons license, and indicate if changes were made. The Creative Commons Public Domain Dedication waiver (http://creativecommons.org/publicdomain/zero/1.0/) applies to the data made available in this article, unless otherwise stated. 


\section{Background}

Diabetes mellitus (DM) is responsible for high global mortality rates and high disability burden [1] and is a major risk factor for cardiovascular disease. The presence of both DM and cardiovascular disease (CVD) increases the risk of death [2-5]. The global prevalence of DM has almost doubled in the adult population since 1980 (4.7 to $8.5 \%)$. In 2012, 1.5 million people died by DM. High blood glucose levels caused an additional 2.2 million deaths due to increased cardiovascular risk and other diseases. The percentage of deaths attributable to high blood glucose or diabetes that occurs prior to age 70 is higher in low- and middle-income countries (LMICs) than in high-income countries (HICs) [6].

In the world, $80 \%$ of cases of noncommunicable diseases (NCDs) occur in LMICs [7]. Most countries in Latin America, at least during the last 50 years, have experienced an epidemiological transition within a "prolonged polarized model", presenting complex transformation of their conditions of health, with the existence of a double burden of disease or epidemiological superposition [8, 9]. In Colombia, DM is among the first 10 causes of general mortality and within the first 20 causes of years of healthy life lost (YHLL) in a population $\geq 45$ years [10]. According to several studies in population of high-income countries (HIC), patients with Type 2 DM have a considerably higher risk of cardiovascular morbidity and mortality. However, it is not clear if the magnitude of this association can be widespread in other populations. This has been attributed to older age and a higher prevalence of cardiovascular risk factors among people with diabetes [11]. In observational studies of cases and controls that included participants from Latin America, including Colombia, an association between DM and AMI has been reported. In the INTERHEART study, a significant association between DM and AMI (Odds Ratio (OR) 2.59, 95\% Confidence Interval (CI) 2.09-3.22) and a population risk attributable to DM of $17.2 \%$ was reported [12]. In the INTERSTROKE study, a significant association between DM and stroke (Relative Risk (RR) 1.36, 95\% CI 1.10-1.68) and a population risk attributable to DM of $5 \%$ was reported [13]. In randomized clinical trials such as the NAVIGATOR study, Latin American participants with glucose intolerance had an increased risk of cardiovascular death (Hazard Risk (HR) 2.68, 95\% CI 1.82-3.96) and composite cardiovascular outcome (HR 1.48, 95\% CI 1.15-1.92) [14]. Traditional multivariate risk adjustment models may be limited by residual biases and questioned the reliability and when the data are recorded in the context of a clinical trial, they may not reflect the real characteristics of the population by the specified selection criteria. In addition, there may be variation in the management plans of cardiovascular risk programs even within a given region. Matching propensity scores allow balancing the covariates of baselines measured in the cohorts to obtain more robust results [15].

The objective of this study was to examine the association between Type 2 DM with first cardiovascular event in a cohort of type 2 DM Colombian Caribbean poor population with no previous records of cardiovascular events compared with a paired matched cohort of patients with no presence of DM.

\section{Methods \\ Study population and cohort}

In 2015 Colombia had 48.2 million people. 10.3 million of them live in the Caribbean Region. For this study, patients from a Colombian public health insurance company were selected. By 2015, it had 1.2 million insured people from poor households of the Colombian Caribbean region $(11.6 \%$ of the population in the Caribbean region). $49 \%$ are male, sex ratio $1: 1$ and 54\% are under 30 years old, which indicates a representative and very similar population structure to the Colombian Caribbean region [16].

The insurance company have a cardiovascular risk management program, which performs screening of cardiovascular risk factors and the detection of cardiovascular events in the affiliated population. Screened patients who reported presence of risk factors were enrolled in the cardiovascular risk management program, which carry out a plan of follow-up activities according to the stratification of cardiovascular risk from the Framingham Risk Score.

Sociodemographic and clinical characteristics of enrolled patients from the program are registered in a private platform of the health insurance company. For the current investigation, we had access to the individual records of service provision registered between July 2014 and December 2015. In 2015, there were 64,668 (66.5\% women) patients enrolled in the program. More than $90 \%$ of them were over 45 years old.

\section{History of type 2 diabetes mellitus}

Patients with type $2 \mathrm{DM}$ were identified through at least once of the following characteristics: having ICD -10 diagnosis code, having a personal reported history of DM, having glycosylated hemoglobin levels $>6.5 \%$ at least once in records and those under anti-diabetic treatment. From the identified patients, we excluded the ones with a personal history of previous cardiovascular events, and diabetics younger than 30 years under treatment with insulin and without oral anti-diabetics.

\section{Study outcomes}

For the current analysis, the main outcome were first CVD events related endpoints: such as acute myocardial infarction, angina pectoris, acute stroke, mortality due to 
CVD, and hospitalization due to CVD during 1.5 years of follow-up (12,7 average months of follow-up and range, 1-18 months). CVD events were confirmed by ICD-10 diagnosis CVD events related endpoints from the cardiovascular risk management program hospitalizations database. Follow-up was censored with presence of cardiovascular events, death, or the end of the study, whichever occurred first.

For the current investigation, we had access to hospitalizations records between July 2014 and December 2015, which were previously verified by the internal auditors of the health insurance company. The exact date of death of the patients was not available. So the date of hospitalization due to cardiovascular events or any other date was considered and imputed as the date of death in patients registered as "deceased" in the database of the program whose date of hospitalization was after the date of the last monitoring control observed. In the patients registered as "deceased" who did not have a record of hospitalizations, the median date between the date of the last control observed and the expected date of the next control was considered as the date of death.

\section{Covariates and propensity score matching}

We used the propensity score method and performed 1:1 nearest-neighbor matching without replacement due to imbalances in baseline characteristics between patients with and without Type 2 DM. We used a non-parsimonious multivariable logistic regression model to estimate propensity scores for Type $2 \mathrm{DM}$. In the model, Type $2 \mathrm{DM}$ was the dependent variable and clinically relevant baseline characteristics were used as covariates. Then a $P$ value of less 0.20 was defined for selecting variables for entry into the final model. Selected variables were as follows: age, sex, smoking, physical activity, hypertension, obesity, hyperlipidemia, chronic kidney disease (CKD), hypertension control, Angiotensin-Converting Enzyme Inhibitors (ACEI)-Angiotensin-Receptor Blocker (ARB), calcium-antagonists, statins, antiplatelet and number of anti-hypertensive drugs. By using these covariates, a propensity score was calculated for each patient. Finally, each patient who underwent Type $2 \mathrm{DM}$ was matched to one patient who underwent no Type $2 \mathrm{DM}$ with the closest propensity score. The maximum difference of propensity score for a match was less than 0.03 . To ensure that the post-match comparisons between patients with and without diabetes were not affected by the small sample size of the matched cohort, we assembled a pre-match cohort of the same sample size as that of the matched cohort. This was done by first identifying the 18,449 patients with diabetes in the matched cohort. Then, we identified a random sample of 18,449 patients without diabetes from the entire pre-match sample of 36,898 patients without diabetes. Finally, we linked these two data sets, thus assembling a cohort of 18,449 pairs of patients with and without diabetes.

\section{Statistical analysis}

Baseline characteristics were presented through absolute and relative frequencies and means with standard deviations. We used Pearson Chi-square and Wilcoxon Rank-Sum tests for the pre-match comparison and paired sample t-test for the post-match comparisons of baseline covariates between patients with and without DM. The Kaplan-Meier curves were constructed for the cardiovascular events related endpoints and matched Cox-regression analysis to estimate associations of a history of Type $2 \mathrm{DM}$ with cardiovascular outcomes during 1.5 years of follow-up. Log-minus-log scale risk plots were used to check proportional hazards assumptions. A formal sensitivity analysis using The Breslow-Day and Tarone Homogeneity tests was conducted. All statistical analyses were conducted using the Stata version 14.2 software (StataCorp, College Station, TX) and R version 3.4.3 ( $\mathrm{R}$ Core Team, $\mathrm{R}$ Foundation for Statistical Computing). $P$ value $<0.05$ was considered statistically significant for all tests.

\section{Results}

\section{Baseline characteristics before propensity matching}

All 56,351 patients included in the study are from a low socioeconomic level. We could not access to information on educational level, civil status and other sociodemographic characteristics due to restrictions of the insurance company. After identification, 19,368 (34.4\%) patients were identified through the Type 2 DM records as follow; 14,131 (73\%) by the ICD-10 diagnosis of DM, $323(1.7 \%)$ by a personal history of DM, $2334(12.1 \%)$ by glycosylated hemoglobin levels $>6.5 \%$ at least once and $2579(13.3 \%)$ by the reported treatment with anti-diabetic medicines. Patients were significantly younger in the personal history of Type 2 DM (-) group compared with the personal history of Type $2 \mathrm{DM}(+)$ group $(63.6 \pm 13.1$ years old versus $65.6 \pm 13.6$ years old); the number of anti-hypertensive drugs in the personal history of Type 2 $\mathrm{DM}(+)$ group is lower compared with the personal history of Type $2 \mathrm{DM}(-)$ group $(0.69 \pm 0.45$ versus $0.72 \pm$ 0.44). 36.7\% achieved good metabolic control (glycosylated hemoglobin $<7 \%$ ).

The incidence rate of first cardiovascular event in $>65$ years old was $22.9 / 1000$ person - year (95\% CI 21.0 25.0) (Incidence Rate Ratio (IRR) 3.15 when $\geq 65$ years old group was compared with $<65$ years old group, $95 \%$ IC 2.65-3.75). The incidence rate of first acute myocardial infarction or angina pectoris event (AMI) in $>65$ years old was 13.9/1000 person - year (95\% CI 12.4 $15.5)$ (IRR) 2.63 when $\geq 65$ years old group was compared with $<65$ years old group, 95\% IC 2.14-3.26). The 
incidence rate stroke in $>65$ years old was $9.31 / 1000$ person - year (95\% CI 8.13-10.67) (IRR 4.68 when $\geq 65$ years old group was compared with $<65$ years old group, 95\% IC 3.41-6.53).

There were several parameters of baseline characteristics statistically higher in the family history of DM $(+)$ group, including the percentage of female gender (68.07\% vs. $65.33 \%)$, hypertension control $(90.74 \%$ vs. $89.28 \%)$, use of antiplatelet ( $41.59 \%$ vs. $37.12 \%)$ and use of statins $(52.05 \%$ vs. $44.54 \%)$. The incidence rate of first cardiovascular event in man was $20.9 / 1000$ person year (95\% CI 18.6-23.5) (IRR 1.49 when men's group was compared with women's group, 95\% IC 1.29-1.72). The incidence rate of AMI in man was $14.2 / 1000$ person - year (95\% CI 13.3-16.3) (IRR 1.66 when men's group was compared with women's group, 95\% IC 1.38-1.99). The incidence rate of stroke in man was 6.95/1000 person - year (95\% CI 5.67-8.51) (IRR 1.23 when men's group was compared with women's group, 95\% IC 0.96-1.67).

Among 19,368 subjects with a personal history of Type $2 \mathrm{DM}(+)$ group, 667 (3.4\%) subjects had a first cardiovascular event before propensity score matching. Among 18,449 subjects with a personal history of Type 2 DM (+) group, $650(3.5 \%)$ subjects had a first cardiovascular event after propensity score matching. The incidence rate of first cardiovascular event was 22.2/1000 person year (95\% CI 19.9-24.7) (IRR 1.86 when Type 2 DM (+) group was compared with Type 2 DM (-) group, 95\% IC 1.65-2.15). The incidence rate of AMI was 14.4/1000 person - year (95\% CI 12.6-16.4) (IRR 2.00 when Type 2 DM (+) group was compared with Type 2 DM (-) group, 95\% IC 1.67-2.39). The incidence rate of stroke was 8.05/1000 person - year (95\% CI 6.73-9.63) (IRR 1.66 when Type $2 \mathrm{DM}(+)$ group was compared with Type 2 DM (-) group, 95\% IC 1.31-2.11).

Among 19,368 subjects with a personal history of Type 2 DM (+) group, 3418 (17.4\%) subjects were under treatment of human or analogous insulin. Of these, 213 (6.2\%) subjects had a first cardiovascular event before propensity score matching. The incidence rate of first cardiovascular event was 41.01/1000 person - year (95\% CI 34.08-49.36) (IRR 2.05 when Type 2 DM (+) group under human or analogous insulin treatment was compared with Type $2 \mathrm{DM}(+)$ group without treatment with human or analogous insulin, 95\% IC 1.73-2.42). The incidence rate AMI was 27.4/1000 person - year (95\% CI 21.90-34.44) (IRR 2.03 when Type 2 DM (+) group under human or analogous insulin treatment was compared with Type $2 \mathrm{DM}(+)$ group without treatment with human or analogous insulin, 95\% IC 1.652.50). The incidence rate of stroke was $14.64 / 1000$ person - year (95\% CI 10.74-19.97) (IRR 2.13 when Type 2 DM (+) group under human or analogous insulin treatment was compared with Type 2 DM (+) group without treatment with human or analogous insulin, 95\% IC 1.60-2.80).

To explore this imbalance, we illustrate a histogram of propensity score distribution for groups with and without personal history Type 2 DM before Fig. 1 (a) and after Fig. 1 (b) propensity matching.

\section{Baseline characteristics after Propensity matching}

According to the propensity score matching 1:1 shown in Table 1, 18,446 patients in the personal history of Type $2 \mathrm{DM}(+)$ group were matched with 18,446 in the personal history of Type 2 DM (-) group. All absolute standardized differences after the match for all covariates were $<5 \%$ and showed sufficient overlap in the estimated propensity scores. The characteristics of propensity score-matched patients with $(n=18,449)$ and without $(n=18,449)$ Type $2 \mathrm{DM}$ are shown in Table 1.

\section{Type 2 DM and first CVD Events}

In the group with and without a personal history of DM type 2, the first CVD event occurred in 650 (3.5\%) and $403(2.1 \%)$ patients, respectively (incidence rate 22.1/ 1000 person - year (95\% IC 19.8-24.6) and HR 1.69; 95\% CI 1.43-2.00; Fig. 2). In the subgroups analysis, the homogeneous association that a personal history of DM type 2 had with the first CVD event in a broad spectrum of patients was estimated (Table 2).

In the group with and without a personal history of DM type 2, the first acute myocardial infarction or angina pectoris event (AMI) occurred in 424 (2.3\%) and $254(1.3 \%)$ patients, respectively (incidence rate 14.4 person -year (95\% CI 12.6-16.5); HR 1.79; 95\% CI $1.45-$ 2.20; $p=0.000$; Fig. 2 and Table 3). In the group with and without a personal history of DM type 2, the first acute stroke event occurred in 234 (1.2\%) and 153 $(0.8 \%)$ patients, respectively (incidence rate 8,1 / 1000 person - year (95\% CI 6,7 - 9,6); HR 1.54; 95\% CI 1.182.02; $p=0.001$; Fig. 2 and Table 4).

\section{Type 2 DM and other outcomes}

Significant unadjusted associations were estimated between the personal history of DM type 2 and several outcomes among the pre-match cohort. Among the 36,898 balanced cohorts, type 2 DM was associated with an increased risk of hospitalization from any cause and association with cardiovascular death, stroke death, and death from all causes (Table 5).

\section{Discussion}

The data from the Framingham Heart Study made it possible to identify DM as an important cardiovascular risk factor, mainly in women [17]. To the best of our knowledge, this is the first report of an association between Type $2 \mathrm{DM}$ and first cardiovascular events in a 

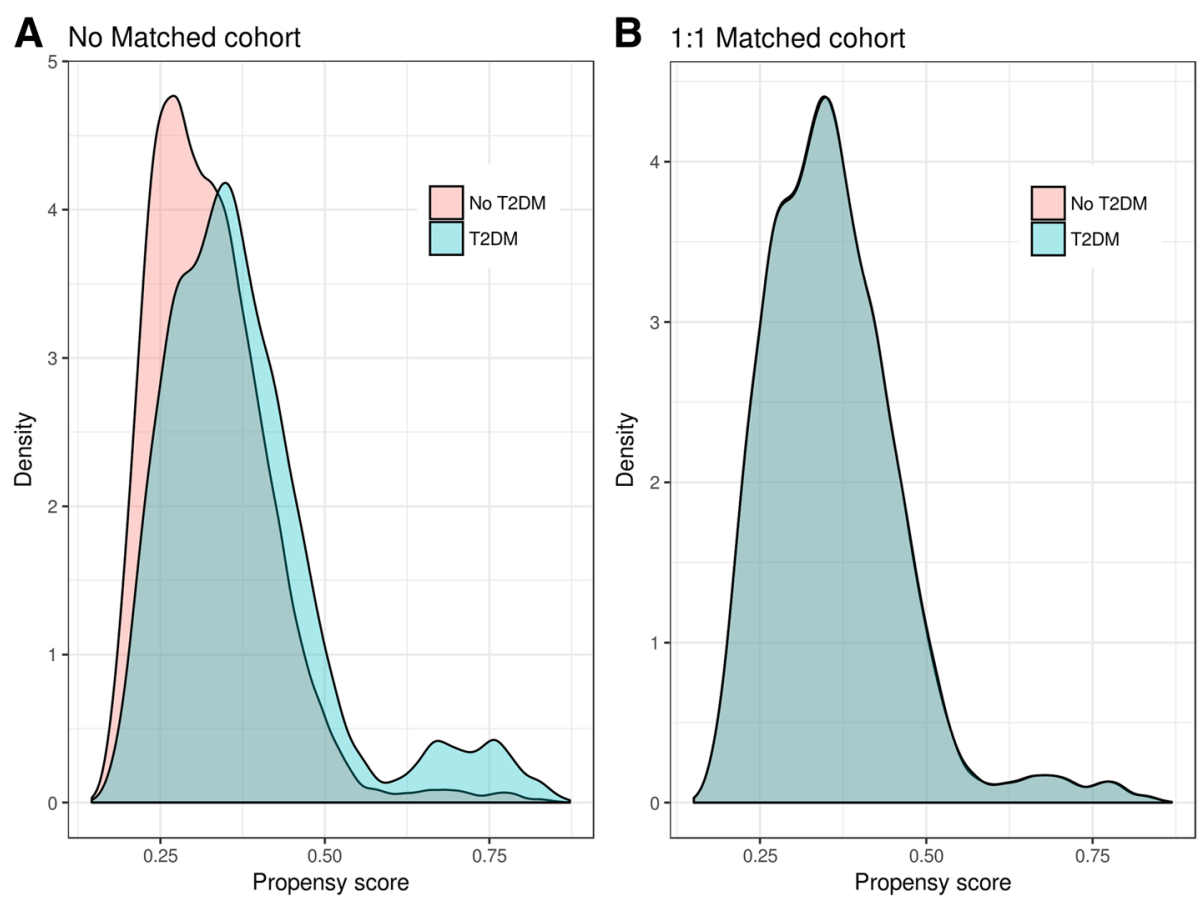

Fig. 1 Propensity score distribution before (a-No Matchet cohort) and after (b-Matchet cohort) propensity score matching

propensity-matched cohort of poor population without a history of previous cardiovascular events in Latin America and Colombia. According to several studies, all patients with DM can be treated as if they had prior cardiovascular disease since the risk of fatal AMI in patients with DM without previous AMI is similar to that of patients without DM who have survived an AMI $[11,17]$. In the study of Becker et al., 10-year follow-up, women with DM, but without prior cardiovascular disease have a risk of cardiovascular events that is similar to that of women without diabetes but with prior cardiovascular disease, whereas in men the presence of prior cardiovascular disease conferred a higher risk [11]. In our study, in the pre-matched cohort, the risk of the first cardiovascular event was significantly higher in women with Type 2 DM. In the post-matched cohort, these differences by sex disappeared for almost all outcomes, except for the stroke incidence that was significantly higher in women with Type 2 DM. In the Framingham Heart Study for stroke, women with DM had a higher incidence than men did with DM [17].

The findings of the current analysis demonstrate that in patients without a personal history of previous cardiovascular events, a history of Type $2 \mathrm{DM}$ was associated with an increased risk of a first cardiovascular event, which was primarily driven by an increase in AMI. Type 2 DM was also associated with risk of all-cause hospitalization, cardiovascular death, stroke death and all-cause death, but had no independent association with cardiovascular hospitalization. In the Framingham Heart Study, an increased mortality due to CVD in patients with DM compared with patients without DM was reported [17]. In the INTERHEART study, a significant association between DM and AMI (OR 2.59, 95\% CI 2.09-3.22) and a population risk attributable to DM of $17.2 \%$ was reported [12]. In the INTERSTROKE study, a significant association between DM and stroke (RR 1.36, 95\% CI 1.10-1.68) and a population risk attributable to DM of $5 \%$ was reported [13]. These results should be interpreted considering the limitations and possible biases of a case-control study, in which the presence of exposure variables is determined after the onset of the disease [18]. In randomized clinical trials such as the NAVIGATOR study, Latin American participants with glucose intolerance had an increased risk of cardiovascular death (HR 2.68, 95\% CI 1.82-3.96) and composite cardiovascular outcome (HR 1.48, 95\% CI 1.15-1.92). When the data are recorded in the context of a clinical trial, they may not reflect the real characteristics of the population by the specified selection criteria [14]. In the PURE study identified that although risk-factor burden may be lower in LMIC, the risk of cardiovascular events was much higher [19]. In the current study, the risk of first cardiovascular event was significantly higher in the Type 2 DM group (HR 1.69; 95\% CI 1.43-2.00).

In Colombia, DM is among the first 10 causes of general mortality and within the first 20 causes of years of healthy life lost (YHLL) in a population $\geq 45$ years [10]. 
Table 1 Baseline Characteristics by history of Type 2 DM before and after propensity Matching cohort

\begin{tabular}{|c|c|c|c|c|c|c|}
\hline \multirow[b]{2}{*}{$n(\%) /$ mean $( \pm s d)$} & \multicolumn{3}{|c|}{ Before propensity matching $(N=56,351)$} & \multicolumn{3}{|c|}{ After propensity matching $(N=36,898)$} \\
\hline & No T2DM & T2DM & $\mathrm{P}$ & No T2DM & T2DM & $\mathrm{P}$ \\
\hline \multirow[t]{2}{*}{ Women } & 24,495 & 13,299 & $<0.001$ & 12,741 & 12,644 & 0.276 \\
\hline & 66.23 & 68.66 & & 69.06 & 68.53 & \\
\hline Age & $65.50(+-13.66)$ & $63.24(+-13.08)$ & $<0.001$ & $63.7(+-13.5)$ & $63.8(+-13.0)$ & 0.7186 \\
\hline \multirow[t]{2}{*}{ Hypertension } & 36,444 & 17,998 & $<0.001$ & 17,915 & 17,935 & 0.531 \\
\hline & 98.54 & 92.93 & & 97.11 & 97.21 & \\
\hline \multirow[t]{2}{*}{ Dyslipidemia } & 31,323 & 16,685 & $<0.001$ & 15,956 & 15,983 & 0.680 \\
\hline & 84.7 & 86.15 & & 86.49 & 86.63 & \\
\hline \multirow[t]{2}{*}{ Obesity } & 14,323 & 9700 & $<0.001$ & 9278 & 9315 & 0.700 \\
\hline & 38.73 & 50.08 & & 50.29 & 50.49 & \\
\hline \multirow[t]{2}{*}{ Controlled Hypertension } & 33,096 & 17,582 & $<0.001$ & 16,652 & 16,702 & 0.377 \\
\hline & 89.49 & 90.78 & & 90.26 & 90.53 & \\
\hline \multirow[t]{2}{*}{ CKD } & 5440 & 3184 & $<0.001$ & 3040 & 3034 & 0.933 \\
\hline & 14.71 & 16.44 & & 16.48 & 16.45 & \\
\hline Number of antihypertensive drugs & $0.72(+-0.44)$ & $0.67(+-0.46)$ & $<0.001$ & $1.81(+-1.66)$ & $1.82(+-1.8)$ & 0.227 \\
\hline \multirow[t]{2}{*}{ ACEI-ARB } & 24,218 & 12,126 & $<0.001$ & 12,075 & 12,072 & 0.974 \\
\hline & 65.48 & 62.61 & & 65.45 & 65.43 & \\
\hline \multirow[t]{2}{*}{ Antiplatelet } & 12,957 & 7492 & $<0.001$ & 7242 & 7347 & 0.264 \\
\hline & 35.04 & 38.68 & & 39.25 & 39.82 & \\
\hline \multirow[t]{2}{*}{ Calcium Antagonists } & 9943 & 5878 & $<0.001$ & 5776 & 5817 & 0.646 \\
\hline & 26.89 & 30.35 & & 31.31 & 31.53 & \\
\hline \multirow[t]{2}{*}{ Statins } & 15,624 & 9672 & $<0.001$ & 9323 & 9382 & 0.539 \\
\hline & 42.25 & 49.94 & & 50.53 & 50.85 & \\
\hline \multirow[t]{2}{*}{ Insulin } & 0 & 3418 & $<0.001$ & 0 & 3222 & $<0.001$ \\
\hline & 0 & 17.65 & & 0 & 17.46 & \\
\hline \multirow[t]{2}{*}{ Human Insulin } & 0 & 1604 & $<0.001$ & 0 & 1497 & $<0.001$ \\
\hline & 0 & 8.28 & & 0 & 8.11 & \\
\hline \multirow[t]{2}{*}{ Analogous Insulin } & 0 & 2503 & $<0.001$ & 0 & 2375 & $<0.001$ \\
\hline & 0 & 12.92 & & 0 & 12.87 & \\
\hline \multirow[t]{2}{*}{ Sulfonylureas } & 0 & 5852 & $<0.001$ & 0 & 5548 & $<0.001$ \\
\hline & 0 & 30.21 & & 0 & 30.07 & \\
\hline \multirow[t]{2}{*}{ Metformin } & 0 & 8430 & $<0.001$ & 0 & 7950 & $<0.0010$ \\
\hline & 0 & 43.53 & & 0 & 43.09 & \\
\hline \multirow[t]{2}{*}{ DPP4-I } & 0 & 677 & $<0.001$ & 0 & 648 & $<0.001$ \\
\hline & 0 & 3.5 & & 0 & 3.51 & \\
\hline \multirow[t]{2}{*}{ GLP1 receptor agonists } & 0 & 88 & $<0.001$ & 0 & 85 & $<0.001$ \\
\hline & 0 & 0.45 & & 0 & 0.46 & \\
\hline
\end{tabular}

In Colombia, according to data from individual health care records (RIPS) and systematic reviews between 2010 and 2014, approximately 1,500,000 patients with type 2 DM were estimated [10]. According to the National Department of Statistics (DANE) of Colombia, between January 2016 and August 2018, 60,944 deaths from ischemic heart disease (17.1\%), 24,548 deaths from cerebrovascular diseases (6.9\%) and 11,743 deaths from DM (3.3\%), were estimated. According to the cumulative incidence of first cardiovascular events (3.5\%) and cardiovascular mortality (22.9\%) in Type 2 DM group (+) estimated in the current study, approximately 52,500 first-time cardiovascular events and around 12,000 cardiovascular deaths per year would be expected to occur. 


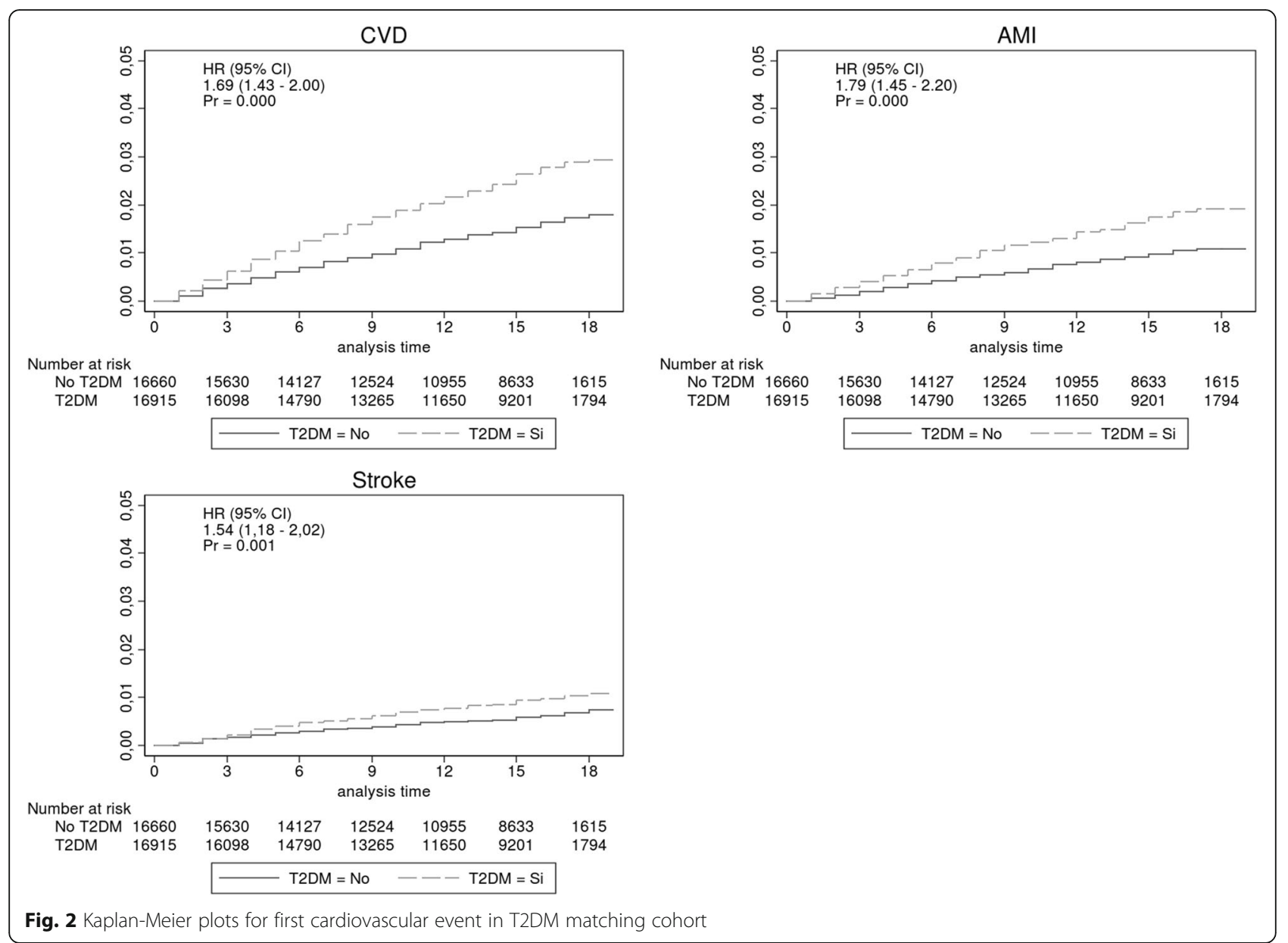

These estimates are similar to the annual deaths due to DM estimated by the International Diabetes Federation (IDF) $(11,400$ deaths due to DM) [6] and the non-fetal death statistics of the DANE of Colombia (11,743 deaths due to DM).

Care of a patient with DM requires a multifactorial approach from the cardiovascular risk management program. All patients are at risk of developing vascular complications of DM, and these risks represents ultimately result in a doubled risk of mortality in patients with DM. Above and beyond targeted interventions, we now know that strict multifactorial interventions can result in a clinically significant reduction in both mortality and cardiovascular disease. These conclusions provide significant information on the importance of Type 2 DM in increasing the risk of first cardiovascular events in the poor population of the Colombian Caribbean region and the importance of an adequate diagnosis and treatment of Type 2 DM. However, evidence that an adequate metabolic control reduces the rates of cardiovascular events and death is not clear, although a discrete cardiovascular benefit may be observed after a prolonged follow-up period [20-24]. Evidence from HICs indicates that multiple risk factor intervention programmes do not result in reductions in cardiovascular events but may be effective in reducing mortality in high-risk hypertensive and diabetic populations. Due to the differences in the structure of the communities and the target population, caution is needed to generalize the results to LMICs. In the systematic review of Uthman et al., evidence about effectiveness of multiple risk factor interventions (with or without pharmacological treatment) in LMICs was scarce and only one study reported cardiovascular outcomes and multiple risk factor interventions did not reduce the incidence of cardiovascular events and none of the included trials reported all-cause mortality [25]. For cardiovascular risk management programs it is important to evaluate the impact of their interventions over time to achieve optimal primary cardiovascular prevention in patients under the care of the program [26]. There may be variation in the management plans of cardiovascular risk programs even within a given region beyond differences in health budget and system characteristics [27]. The use of statins in the LMIC is low in comparison with the HIC [28]. In the NAVIGATOR study, was reported that patients in Latin 
Table 2 Association of a history of Type 2 DM and first event cardiovascular

\begin{tabular}{|c|c|c|c|c|c|c|c|}
\hline & \multicolumn{5}{|c|}{ T2DM (event/N) } & \multirow[t]{2}{*}{ Effect } & \multirow{2}{*}{$\begin{array}{l}\text { Breslow-Day } \\
\text { homogeneity } \\
\text { test }\end{array}$} \\
\hline & No & Yes & OR & IC95 & & & \\
\hline \multicolumn{8}{|l|}{ Sex } \\
\hline Women & 207/12741 & $370 / 12644$ & 1.825 & 1.532 & 2.176 & 0.452 & 0.056 \\
\hline Men & $196 / 5708$ & $280 / 5805$ & 1.425 & 1.178 & 1.725 & 0.298 & \\
\hline \multicolumn{8}{|l|}{ Age } \\
\hline$<65$ years & 136/9807 & 196/9719 & 1.464 & 1.168 & 1.838 & 0.317 & 0.238 \\
\hline$>=65$ years & $267 / 8642$ & $454 / 8730$ & 1.721 & 1.471 & 2.014 & 0.419 & \\
\hline \multicolumn{8}{|l|}{ CKD } \\
\hline No & $308 / 15409$ & $503 / 15415$ & 1.654 & 1.429 & 1.914 & 0.395 & 0.760 \\
\hline Yes & $95 / 3040$ & $147 / 3034$ & 1.578 & 1.205 & 2.076 & 0.366 & \\
\hline \multicolumn{8}{|c|}{ Controlled Hypertension } \\
\hline No & $47 / 1797$ & $76 / 1747$ & 1.693 & 1.154 & 2.505 & 0.409 & 0.847 \\
\hline Yes & $356 / 16652$ & $574 / 16702$ & 1.629 & 1.422 & 1.867 & 0.386 & \\
\hline \multicolumn{8}{|l|}{ Dyslipidemia } \\
\hline No & $18 / 2493$ & $33 / 2466$ & 1.865 & 1.016 & 3.526 & 0.464 & 0.647 \\
\hline Yes & $385 / 15956$ & $617 / 15983$ & 1.624 & 1.424 & 1.852 & 0.384 & \\
\hline \multicolumn{8}{|l|}{ Obesity } \\
\hline No & 242/9171 & $385 / 9134$ & 1.624 & 1.374 & 1.918 & 0.384 & 0.873 \\
\hline Yes & $161 / 9278$ & 265/9315 & 1.658 & 1.354 & 2.034 & 0.397 & \\
\hline \multicolumn{8}{|l|}{ Hypertension } \\
\hline No & $1 / 534$ & $0 / 514$ & & & & & $0.2095^{\mathrm{a}}$ \\
\hline Yes & $402 / 17915$ & $650 / 17935$ & 1.638 & 1.441 & 1.862 & 0.390 & \\
\hline \multicolumn{8}{|l|}{ ACEI-ARB } \\
\hline No & $37 / 6374$ & $47 / 6377$ & 1.272 & 0.808 & 2.015 & 0.214 & 0.225 \\
\hline Yes & $366 / 12075$ & $603 / 12072$ & 1.682 & 1.470 & 1.924 & 0.405 & \\
\hline \multicolumn{8}{|c|}{ Calcium Antagonist } \\
\hline No & $169 / 12673$ & 269/12632 & 1.610 & 1.320 & 1.964 & 0.379 & 0.815 \\
\hline Yes & $234 / 5776$ & $381 / 5817$ & 1.660 & 1.400 & 1.969 & 0.398 & \\
\hline \multicolumn{8}{|l|}{ Statins } \\
\hline No & $61 / 9126$ & $92 / 9067$ & 1.523 & 1.089 & 2.143 & 0.344 & 0.632 \\
\hline Yes & $342 / 9323$ & $558 / 9382$ & 1.661 & 1.444 & 1.910 & 0.398 & \\
\hline \multicolumn{8}{|l|}{ Antiplatelet } \\
\hline No & $95 / 11207$ & $144 / 11102$ & 1.537 & 1.176 & 2.016 & 0.349 & 0.599 \\
\hline Yes & $308 / 7242$ & $506 / 7347$ & 1.665 & 1.436 & 1.931 & 0.399 & \\
\hline \multicolumn{8}{|c|}{ Number antihypertensive drugs } \\
\hline$<2$ & $49 / 9062$ & $68 / 9421$ & 1.337 & 0.912 & 1.973 & 0.252 & 0.172 \\
\hline$>=2$ & $354 / 9387$ & $582 / 9028$ & 1.758 & 1.532 & 2.018 & 0.431 & \\
\hline
\end{tabular}

${ }^{a}$ Tarone's homogeneity test

America used fewer therapies for prevention of cardiovascular events, such as aspirin (32\% versus $47 \%$ in North America and 35\% in Europe), lipid-lowering therapies $(28 \%$ versus $55 \%$ in North America and $35 \%$ in Europe), and ACEIs (4\% versus 9\% in North America and $8 \%$ in Europe) [14]. In the TECOS study, low use of statins and aspirin in Latin America compared to North America was reported [29]. Recently, trials evaluating anti-diabetic drugs (empagliflozin, liraglutide, pioglitazone and semaglutide) have shown improved cardiovascular 
Table 3 Association of a history of Type 2 DM and first event AMI

\begin{tabular}{|c|c|c|c|c|c|c|c|}
\hline & \multicolumn{5}{|c|}{ T2DM (event/N) } & \multirow[t]{2}{*}{ Effect } & \multirow{2}{*}{$\begin{array}{l}\text { Breslow-Day } \\
\text { homogeneity } \\
\text { test }\end{array}$} \\
\hline & No & Yes & OR & IC95 & & & \\
\hline \multicolumn{8}{|l|}{ Sex } \\
\hline Women & 133/12741 & 228/12644 & 1.741 & 1.397 & 2.175 & 0.426 & 0.636 \\
\hline Men & $133 / 5708$ & $228 / 5805$ & 1.613 & 1.276 & 2.047 & 0.380 & \\
\hline \multicolumn{8}{|l|}{ Age } \\
\hline$<65$ years & 100/9807 & 144/9719 & 1.460 & 1.121 & 1.906 & 0.315 & 0.176 \\
\hline$>=65$ years & $154 / 8642$ & 280/8730 & 1.826 & 1.491 & 2.243 & 0.452 & \\
\hline \multicolumn{8}{|l|}{ CKD } \\
\hline No & 198/15409 & $330 / 15415$ & 1.681 & 1.402 & 2.015 & 0.405 & 0.944 \\
\hline Yes & $56 / 3040$ & $94 / 3034$ & 1.704 & 1.206 & 2.424 & 0.413 & \\
\hline \multicolumn{8}{|l|}{ Control HTA } \\
\hline No & $31 / 1797$ & $48 / 1747$ & 1.609 & 0.998 & 2.629 & 0.585 & 0.385 \\
\hline Yes & 223/16652 & $376 / 16702$ & 1.697 & 1.431 & 2.012 & 0.398 & \\
\hline \multicolumn{8}{|l|}{ Dyslipidemia } \\
\hline No & $8 / 2493$ & $19 / 2466$ & 2.412 & 1.006 & 6.379 & 0.464 & 0.647 \\
\hline Yes & 246/15956 & $405 / 15983$ & 1.660 & 1.410 & 1.955 & 0.384 & \\
\hline \multicolumn{8}{|l|}{ Obesity } \\
\hline No & 146/9171 & 246/9134 & 1.711 & 1.385 & 2.119 & 0.416 & 0.835 \\
\hline Yes & 108/9278 & 178/9315 & 1.654 & 1.293 & 2.124 & 0.395 & \\
\hline \multicolumn{8}{|l|}{ Hypertension } \\
\hline No & $1 / 534$ & $0 / 514$ & & & & & $0.2026^{a}$ \\
\hline Yes & 253/17915 & 424/17935 & 1.690 & 1.440 & 1.984 & 0.408 & \\
\hline \multicolumn{8}{|l|}{ ACEI-ARB } \\
\hline No & $22 / 6374$ & $25 / 6377$ & 1.136 & 0.614 & 2.116 & 0.120 & 0.159 \\
\hline Yes & 232/12075 & $399 / 12072$ & 1.745 & 1.476 & 2.062 & 0.427 & \\
\hline \multicolumn{8}{|c|}{ Calcium Antagonist } \\
\hline No & $120 / 12673$ & $191 / 12632$ & 1.606 & 1.270 & 2.038 & 0.377 & 0.577 \\
\hline Yes & $134 / 5776$ & 233/5817 & 1.757 & 1.410 & 2.196 & 0.431 & \\
\hline \multicolumn{8}{|l|}{ Statins } \\
\hline No & $25 / 9126$ & $55 / 9067$ & 2.222 & 1.359 & 3.723 & 0.550 & 0.223 \\
\hline Yes & 229/9323 & $369 / 9382$ & 1.626 & 1.371 & 1.929 & 0.385 & \\
\hline \multicolumn{8}{|l|}{ Antiplatelet } \\
\hline No & $44 / 11207$ & $83 / 11102$ & 1.911 & 1.309 & 2.823 & 0.477 & 0.442 \\
\hline Yes & 210/7242 & $341 / 7347$ & 1.630 & 1.363 & 1.949 & 0.386 & \\
\hline \multicolumn{8}{|c|}{ Number antihypertensive drugs } \\
\hline$<2$ & $24 / 9062$ & $34 / 9421$ & 1.364 & 0.785 & 2.406 & 0.267 & 0.324 \\
\hline$>=2$ & 230/9387 & 390/9028 & 1.798 & 1.518 & 2.129 & 0.444 & \\
\hline
\end{tabular}

${ }^{\text {a } T a r o n e ' s ~ h o m o g e n e i t y ~ t e s t ~}$

outcomes in patients with Type 2 DM [30-34]. The findings of the current analysis report a low use of statins, aspirin and new anti-diabetic drugs.

Our study has several strengths and limitations. More than 35 thousand of patients were included and, in spite of the nearly 1000 patients with type $2 \mathrm{DM}$ lost, there were no differences in the incidences and incidence rates between the groups after propensity matching. We tried that the possibility of residual confounding, by the measured covariates and confounding by the unmeasured covariates that explain the associations between Type 2 DM and first cardiovascular event, were unlikely, 
Table 4 Association of a history of Type 2 DM and first event stroke

\begin{tabular}{|c|c|c|c|c|c|c|c|}
\hline & \multicolumn{5}{|c|}{ T2DM (event/N) } & \multirow[t]{2}{*}{ Effect } & \multirow{2}{*}{$\begin{array}{l}\text { Breslow-Day } \\
\text { homogeneity } \\
\text { test }\end{array}$} \\
\hline & No & $\mathrm{Si}$ & OR & IC95 & & & \\
\hline \multicolumn{8}{|l|}{ Sex } \\
\hline Women & 78/12741 & $145 / 12644$ & 1.883 & 1.419 & 2.515 & 0.469 & 0.024 \\
\hline Men & 75/5708 & $89 / 5805$ & 1.169 & 0.848 & 1.615 & 0.145 & \\
\hline \multicolumn{8}{|l|}{ Age } \\
\hline$<65$ years & $37 / 9807$ & $53 / 9719$ & 1.448 & 0.933 & 2.269 & 0.309 & 0.769 \\
\hline$>=65$ years & $116 / 8642$ & 181/8730 & 1.556 & 1.223 & 1.986 & 0.357 & \\
\hline \multicolumn{8}{|l|}{ CKD } \\
\hline No & $112 / 15409$ & $179 / 15415$ & 1.605 & 1.259 & 2.053 & 0.377 & 0.474 \\
\hline Yes & $41 / 3040$ & $55 / 3034$ & 1.350 & 0.882 & 2.082 & 0.260 & \\
\hline \multicolumn{8}{|l|}{ Control HTA } \\
\hline No & 17/1797 & 29/1747 & 1.767 & 0.935 & 3.440 & 0.434 & 0.629 \\
\hline Yes & $136 / 16652$ & 205/16702 & 1.509 & 1.208 & 1.890 & 0.337 & \\
\hline \multicolumn{8}{|l|}{ Dyslipidemia } \\
\hline No & $10 / 2493$ & $15 / 2466$ & 1.520 & 0.637 & 3.790 & 0.342 & 0.980 \\
\hline Yes & $143 / 15956$ & 219/15983 & 1.536 & 1.237 & 1.912 & 0.349 & \\
\hline \multicolumn{8}{|l|}{ Obesity } \\
\hline No & 99/9171 & $145 / 9134$ & 1.478 & 1.135 & 1.931 & 0.323 & 0.617 \\
\hline Yes & $54 / 9278$ & $89 / 9315$ & 1.648 & 1.160 & 2.357 & 0.393 & \\
\hline \multicolumn{8}{|l|}{ Hypertension } \\
\hline No & $0 / 534$ & $0 / 514$ & & & & & $1^{a}$ \\
\hline Yes & 153/17915 & 234/17935 & 1.535 & 1.245 & 1.896 & 0.348 & \\
\hline \multicolumn{8}{|l|}{ ACEI-ARB } \\
\hline No & $16 / 6374$ & $22 / 6377$ & 1.376 & 0.690 & 2.804 & 0.273 & 0.720 \\
\hline Yes & $137 / 12075$ & $212 / 12072$ & 1.558 & 1.249 & 1.948 & 0.358 & \\
\hline \multicolumn{8}{|c|}{ Calcium Antagonist } \\
\hline No & $52 / 12673$ & $81 / 12632$ & 1.566 & 1.091 & 2.264 & 0.362 & 0.886 \\
\hline Yes & $101 / 5776$ & $153 / 5817$ & 1.518 & 1.169 & 1.976 & 0.341 & \\
\hline \multicolumn{8}{|l|}{ Statins } \\
\hline No & $36 / 9126$ & $38 / 9067$ & 1.063 & 0.655 & 1.726 & 0.059 & 0.080 \\
\hline Yes & $117 / 9323$ & 196/9382 & 1.679 & 1.326 & 2.133 & 0.404 & \\
\hline \multicolumn{8}{|l|}{ Antiplatelet } \\
\hline No & $52 / 11207$ & $63 / 11102$ & 1.224 & 0.834 & 1.804 & 0.183 & 0.159 \\
\hline Yes & $101 / 7242$ & $171 / 7347$ & 1.685 & 1.307 & 2.181 & 0.406 & \\
\hline \multicolumn{8}{|c|}{ Number antihypertensive drugs } \\
\hline$<2$ & $26 / 9062$ & $34 / 9421$ & 1.259 & 0.733 & 2.186 & 0.206 & 0.340 \\
\hline$>=2$ & $127 / 9387$ & 200/9028 & 1.652 & 1.313 & 2.084 & 0.395 & \\
\hline
\end{tabular}

${ }^{a}$ Tarone's homogeneity test

considering that our patients were matched in 22 baseline characteristics and the conclusions of our analysis of sensitivity suggest that the association between Type $2 \mathrm{DM}$ and a first cardiovascular event was quite insensitive to an unmeasured binary confounder.
Within limitations, we faced restrictions to access to sociodemographic data due to restrictions from the insurance company. In order to identify the diagnosis of cardiovascular outcomes we used the records of previous cardiovascular events and the ICD-10 hospital discharge 
Table 5 Effect of a history of Type 2 DM and other outcomes

\begin{tabular}{|c|c|c|c|c|c|c|}
\hline$(\mathrm{N} / \%)$ & NO T2DM & T2DM & OR & IC95\% & & $P$ \\
\hline \multicolumn{7}{|l|}{ Before matching } \\
\hline All-cause Hospitalization & $4638(12.54)$ & $4001(20.66)$ & 1.816 & 1.733 & 1.903 & $<0.001$ \\
\hline Cardiovascular hospitalization & $707(15.24)$ & $667(16.67)$ & 1.112 & 0.989 & 1.251 & 0.071 \\
\hline AMI hospitalization & $432(9.31)$ & $434(10.85)$ & 1.185 & 1.027 & 1.367 & 0.018 \\
\hline Stroke hospitalization & $280(6.04)$ & $241(6.02)$ & 0.998 & 0.832 & 1.196 & 0.979 \\
\hline All - cause death & $1077(2.91)$ & $684(3.53)$ & 1.220 & 1.106 & 1.347 & $<0.001$ \\
\hline Cardiovascular death & $168(15.60)$ & $157(22.95)$ & 1.612 & 1.255 & 2.069 & $<0.001$ \\
\hline AMI hospitalization & $94(8.73)$ & $98(14.33)$ & 1.749 & 1.279 & 2.390 & $<0.001$ \\
\hline Stroke hospitalization & $76(7.06)$ & $62(9.06)$ & 1.313 & 0.909 & 1.890 & 0.127 \\
\hline \multicolumn{7}{|l|}{ After matching } \\
\hline All-cause hospitalization & $2443(13.24)$ & 3865 (20.95) & 1.736 & 1.642 & 1.836 & $<0.001$ \\
\hline Cardiovascular hospitalization & $403(16.5)$ & $650(16.82)$ & 1.023 & 0.891 & 1.175 & 0.739 \\
\hline AMI hospitalization & $254(10.4)$ & $424(10.97)$ & 1.062 & 0.898 & 1.256 & 0.474 \\
\hline Stroke hospitalization & $153(6.26)$ & $234(6.05)$ & 0.965 & 0.778 & 1.199 & 0.737 \\
\hline All-cause death & $500(2.71)$ & $676(3.66)$ & 1.365 & 1.212 & 1.538 & $<0.001$ \\
\hline Cardiovascular death & $82(16.4)$ & $156(23.08)$ & 1.529 & 1.126 & 2.085 & 0.005 \\
\hline AMI hospitalization & $46(9.20)$ & $98(14.5)$ & 1.673 & 1.140 & 2.483 & 0.006 \\
\hline Stroke hospitalization & $38(7.6)$ & $61(9.02)$ & 1.206 & 0.776 & 1.893 & 0.385 \\
\hline
\end{tabular}

code. However, we could not have data on confirmatory tests.

On the other hand, the exact date of death of patients and date of enrollment on the cardiovascular risk management program was not available.

We did not have access to information related to the treatment of cardiovascular events such as medications, thrombolysis, percutaneous coronary intervention (PCI), coronary artery bypass surgery (CABG), etc. In conclusion, in the poor population of the Colombian Caribbean without a personal history of cardiovascular events receiving standard therapy, DM produces cardiovascular outcomes. It is not known if a more aggressive screening of DM, DM education at every level, quality care registries and taxes on sugary drinks can reduce the risk of a first cardiovascular event in these patients and should be determined prospectively in future studies in Latin America.

\section{Abbreviations}

AMI: Acute myocardial infarction; CVD: Cardiovascular disease; DANE: Department of Statistics of Colombia; HICs: High-income countries; ICD-10: International statistical classification of diseases and related health problems version 10; LMICs: Low- And Middle-Income Countries; NCDs: Noncommunicable diseases; T2DM: Type 2 diabetes millitus; YHLL: Years of healthy life lost

\section{Acknowledgements}

Not applicable.

\section{Funding}

Not applicable.

\section{Availability of data and materials}

The data that support the findings of this study are from a Subsided Health Insurance Company in Colombia; this information could be obtained making a formal solicitude to them, and may have restrictions of sharing.

\section{Authors' contributions}

PMM and FSM worked on the development of methods and results of the study by analyzing data of patients. JPW and JFM contributed to the study by defining patients inclusion and exclusion criteria and the used methods. FHR and NAG contributed to the discussion of results and overall review of the paper. All authors agreed on results and approved the manuscript.

\section{Ethics approval and consent to participate}

The data collection of this research was approved by the ethics committee of Mutual SER EPS, Fundación SER SOCIAL and ALZAK Foundation, within the framework of the Impact Evaluation of the "De Todo Corazon" program for management of cardiovascular and renal risk in the population affiliated with Mutual SER - EPS and was carried out in accordance with Resolution No. 8430 of 1993 by the Ministry of Health and Social Protection of Colombia. This study was classified as a No Risk investigation, according to the categories established in the aforementioned resolution and the ethics committees dispensed to the authors of the written consent of the informed consent of the participants.

\section{Consent for publication}

Not applicable.

\section{Competing interests}

The authors declare that they have no competing interests.

\section{Publisher's Note}

Springer Nature remains neutral with regard to jurisdictional claims in published maps and institutional affiliations.

\section{Author details}

${ }^{1}$ ALZAK Foundation, 130002, Crespo 70 \#6-99, Cartagena, Colombia. ${ }^{2}$ Mutual SER E.P.S., Cartagena, Colombia. ${ }^{3}$ Universidad Nacional de Colombia, Bogotá, Colombia. ${ }^{4}$ Universidad de Cartagena, Cartagena, Colombia. 
Received: 12 August 2018 Accepted: 26 December 2018 Published online: 08 January 2019

\section{References}

1. Ministerio de Salud y Protección Social. Carga de enfermedad por Enfermedades Crónicas No Transmisibles y Discapacidad en Colombia. 2015 [cited 2017 Dec 13]; Available from: https://www.minsalud.gov.co/sites/rid/ Lists/BibliotecaDigital/RIDE/IA/INS/informe-ons-5.pdf

2. Grundy SM, Benjamin IJ, Burke GL, Chait A, Eckel RH, Howard BV, et al. Diabetes and cardiovascular disease: a statement for healthcare professionals from the American Heart Association. Circulation. 1999;100(10): 1134-46 [cited 2017 Dec 13]. Available from: https://www.ahajournals.org/ doi/abs/10.1161/01.cir.100.10.1134.

3. Wang Q, Liu H, Ding J. Cardiac versus non-cardiac related mortality following percutaneous coronary intervention in patients with insulintreated type 2 diabetes mellitus: a meta-analysis. Diabetes Ther. 2018;9(3): 1335-45 [cited 2018 Nov 5]. Available from: http://link.springer.com/10. 1007/s13300-018-0444-y.

4. Dai X, Luo Z-C, Zhai L, Zhao W-P, Huang F. Reassessing coronary artery bypass surgery versus percutaneous coronary intervention in patients with type 2 diabetes mellitus: a brief updated analytical report (2015-2017). Diabetes Ther. 2018;9(5):2163-71 [cited 2018 Nov 5]. Available from: http:// link.springer.com/10.1007/s13300-018-0504-3.

5. Bundhun PK, Bhurtu A, Yuan J. Impact of type 2 diabetes mellitus on the long-term mortality in patients who were treated by coronary artery bypass surgery: A systematic review and meta-analysis. Medicine (Baltimore). 2017; 96(22):e7022 [cited 2018 Nov 5]. Available from: http://insights.ovid.com/ crossref?an=00005792-201706020-00031.

6. Global Report on Diabetes WHO Library Cataloguing-in-Publication Data. ISBN [Internet]. [cited 2017 Dec 13];978:92-4. Available from: https://www. who.int/diabetes/global-report/en/

7. OMS | Enfermedades no transmisibles. WHO [Internet]. 2017 [cited 2018 Feb 9]; Available from: http://www.who.int/mediacentre/factsheets/fs355/es/

8. Frenk J, Lozano R, Bobadiñla JL. La transición epidemiológica en America Latina. [cited 2018 Feb 9]; Available from: http://repositorio.cepal.org/ bitstream/handle/11362/12808/NotaPobla60_es.pdf?sequence=1

9. Ramos E. Transición Epidemiológica en Colombia: De Las Enfermedades Infecciosas a las No Transmisibles [Internet]. Vol. 3, Revista Ciencias Biomédicas. 2012 [cited 2018 Feb 9]. Available from: http://revistas. unicartagena.edu.co/index.php/cienciasbiomedicas/article/view/1112/1022

10. Observatorio Nacional de Salud. Informe Técnico; Carga de enfermedades por Enfermedades Crónicas No Transmisibles y Discapacidad en Colombia. Bogotá, Colombia; 2015. Available from: https://www.ins.gov.co/Direcciones/ ONS/Resumenes\%20Ejecutivos/ Resumen\%20ejecutivo\%20informe\%205\%20Carga\%20de\%20enfermedad.pdf

11. Becker A, Bos G, de Vegt F, Kostense PJ, Dekker JM, Nijpels G, et al. Cardiovascular events in type 2 diabetes: comparison with nondiabetic individuals without and with prior cardiovascular disease 10-year follow-up of the Hoorn Study. Eur Heart J. 2003;24(15):1406-13 [cited 2018 Feb 10]. Available from: https://academic.oup.com/eurheartj/article-lookup/doi/10. 1016/S0195-668X(03)00197-0.

12. Lanas F, Avezum A, Bautista LE, Diaz R, Luna M, Islam S, et al. Risk factors for acute myocardial infarction in Latin America: the INTERHEART Latin American study. Circulation. 2007;115(9):1067-74 [cited 2018 Mar 27]. Available from: http://www.ncbi.nlm.nih.gov/pubmed/17339564.

13. O'Donnell MJ, Xavier D, Liu L, Zhang H, Chin SL, Rao-Melacini P, et al. Risk factors for ischaemic and intracerebral haemorrhagic stroke in 22 countries (the INTERSTROKE study): a case-control study. Lancet. 2010;376(9735):11223 [cited 2018 Mar 27]. Available from: http://www.ncbi.nlm.nih.gov/ pubmed/20561675.

14. Harumi Higuchi Dos Santos M, Sharma A, Sun J-L, Pieper K, McMurray $J J V$, Holman RR, et al. International variation in outcomes among people with cardiovascular disease or cardiovascular risk factors and impaired glucose tolerance: insights from the NAVIGATOR Trial. J Am Heart Assoc. 2017;6(1):e003892 [cited 2018 Mar 27]. Available from: http://www.ncbi.nlm.nih.gov/pubmed/28087508.

15. D'Agostino RB. Propensity scores in cardiovascular research. Circulation. 2007;115(17):2340-3 [cited 2018 Feb 10]. Available from: http://www.ncbi. nlm.nih.gov/pubmed/17470708.

16. Ministerio de Salud y Protección Social. Análisis de Situación de Salud según regiones Colombia 2013 [Internet]. [cited 2018 Nov 5]. Available from: https://www.minsalud.gov.co/Documentos y Publicaciones/Análisis de situación de salud por regiones.pdf.

17. Qazi MU, Malik S. Diabetes and Cardiovascular Disease: Insights from the Framingham Heart Study. Glob Heart. 2013;8(1):43-8 [cited 2018 Feb 10]. Available from: https://www.sciencedirect.com/science/article/pii/ S2211816013000021.

18. Lanas F, Potthoff S, Mercadal E, Santibáñez C, Lanas A, Standen D. Riesgo individual y poblacional en infarto agudo del miocardio: Estudio INTERHEART Chile. Rev Med Chil. 2008;136(5):555-60 [cited 2018 Mar 28]. Available from: http://www.scielo.cl/scielo.php?script=sci_arttext\&pid= S0034-98872008000500002\&lng=en\&nrm=iso\&tlng=en.

19. Yusuf S, Rangarajan S, Teo K, Islam S, Li W, Liu L, et al. Cardiovascular Risk and Events in 17 Low-, Middle-, and High-Income Countries. N Engl J Med. 2014;371(9):818-27 [cited 2018 Mar 28]. Available from: http://www.ncbi. nlm.nih.gov/pubmed/25162888.

20. Green JB, Bethel MA, Armstrong PW, Buse JB, Engel SS, Garg J, et al. Effect of sitagliptin on cardiovascular outcomes in type 2 diabetes. N Engl J Med. 2015;373(3):232-42 [cited 2017 Dec 13]. Available from: http://www.nejm. org/doi/10.1056/NEJMoa1501352

21. White WB, Cannon CP, Heller SR, Nissen SE, Bergenstal RM, Bakris GL, et al. Alogliptin after Acute Coronary Syndrome in Patients with Type 2 Diabetes. N Engl J Med. 2013;369(14):1327-35 [cited 2017 Dec 13]. Available from: http://www.nejm.org/doi/10.1056/NEJMoa1305889.

22. Scirica BM, Bhatt DL, Braunwald E, Steg PG, Davidson J, Hirshberg B, et al. Saxagliptin and cardiovascular outcomes in patients with type 2 diabetes mellitus. N Engl J Med. 2013;369(14):1317-26 [cited 2017 Dec 13]. Available from: http://www.nejm.org/doi/10.1056/NEJMoa1307684.

23. Holman RR, Paul SK, Bethel MA, Matthews DR, Neil HAW. 10-Year Follow-up of Intensive Glucose Control in Type 2 Diabetes. N Engl J Med. 2008;359(15):157789 Available from: http://www.nejm.org/doi/abs/10.1056/NEJMoa0806470.

24. Gerstein $\mathrm{H}$, Jaeschke R. Empagliflozin, cardiovascular outcomes, and mortality in type 2 diabetes mellitus. Dr. Hertzel Gerstein in an interview with Dr. Roman Jaeschke. Polish Arch Intern Med. 2016;126(10):803-5 [cited 2017 Dec 13]. Available from: http://www.ncbi.nlm.nih.gov/pubmed/27872459.

25. Uthman OA, Hartley L, Rees K, Taylor F, Ebrahim S, Clarke A. Multiple risk factor interventions for primary prevention of cardiovascular disease in low- and middle-income countries. In: Uthman OA, editor. Cochrane Database of Systematic Reviews. Chichester: John Wiley \& Sons, Ltd; 2015. [cited 2017 Dec 14]. Available from: http://doi.wiley.com/10.1002/14651858.CD011163.pub2.

26. Díaz J, Achilli F, Figar S, Waisman G, Langlois E, Galarza C, et al. Prevención de eventos cardiovasculares en hipertensos mayores de 65 años bajo el cuidado de un programa de control. Estudio de cohorte. [Internet]. Vol. 22, Anales de Medicina Interna. Arán Ediciones, S.A; 2005 [cited 2017 Dec 14]. 17-21 p. Available from: http://scielo.isciii.es/scielo.php?script=sci_arttext\&pid=S021271992005000400003

27. Gagliardino JJ, Kleinebreil L, Colagiuri S, Flack J, Caporale JE, Siri F, et al. Comparison of clinical-metabolic monitoring and outcomes and coronary risk status in people with type 2 diabetes from Australia, France and Latin America. Diabetes Res Clin Pract. 2010;88(1):7-13 [cited 2018 Mar 28]. Available from: http://www.ncbi.n/m.nih.gov/pubmed/20153542.

28. Cuevas A, Arteaga A, Rigotti A. A Latin American Perspective on the New ACC/AHA Clinical Guidelines for Managing Atherosclerotic Cardiovascular Disease. [cited 2018 Feb 12]; Available from: http://svmi.web.ve/wh/ intertips/8.VISION-LATINOAMERICANA.pdf

29. Bethel MA, Green JB, Milton J, Tajar A, Engel SS, Califf RM, et al. Regional, age and sex differences in baseline characteristics of patients enrolled in the Trial Evaluating Cardiovascular Outcomes with Sitagliptin (TECOS). Diab Obes Metab. 2015;17(4):395-402 [cited 2018 Mar 28]. Available from: http://www.ncbi.nlm.nih.gov/pubmed/25600421.

30. Zinman B, Wanner C, Lachin JM, Fitchett D, Bluhmki E, Hantel S, et al. Empagliflozin, Cardiovascular Outcomes, and Mortality in Type 2 Diabetes. N Engl J Med. 2015;373(22):2117-28 [cited 2018 Feb 12]. Available from: http://www.nejm.org/doi/10.1056/NEJMoa1504720.

31. Marso SP, Daniels GH, Brown-Frandsen K, Kristensen P, Mann JFE, Nauck MA et al. Liraglutide and Cardiovascular Outcomes in Type 2 Diabetes. N Engl J Med. 2016;375(4):311-22 [cited 2018 Feb 12]. Available from: http://www.nejm.org/doi/ 10.1056/NEMMoa1603827.

32. Erdmann E, Dormandy J, Wilcox R, Massi-Benedetti M, Charbonnel B. PROactive 07: pioglitazone in the treatment of type 2 diabetes: results of the PROactive study. Vasc Health Risk Manag. 2007;3(4):355 [cited 2018 Feb 12]. Available from: https://www.ncbi.nlm.nih.gov/pmc/articles/PMC2291341/. 
33. Kernan WN, Viscoli CM, Furie KL, Young LH, Inzucchi SE, Gorman M, et al. Pioglitazone after Ischemic Stroke or Transient Ischemic Attack. N Engl J Med. 2016;374(14):1321-31 [cited 2018 Feb 12]. Available from: http://www.nejm.org/doi/10.1056/NEJMoa1506930.

34. Dormandy JA, Charbonnel B, Eckland DJ, Erdmann E, Massi-Benedetti M, Moules IK, et al. Secondary prevention of macrovascular events in patients with type 2 diabetes in the PROactive Study (PROspective pioglitAzone Clinical Trial In macroVascular Events): a randomised controlled trial. Lancet. 2005;366(9493):1279-89 [cited 2018 Feb 12]. Available from:

http://www.thelancet.com/article/S0140-6736(05)67528-9/abstract.

Ready to submit your research? Choose BMC and benefit from:

- fast, convenient online submission

- thorough peer review by experienced researchers in your field

- rapid publication on acceptance

- support for research data, including large and complex data types

- gold Open Access which fosters wider collaboration and increased citations

- maximum visibility for your research: over $100 \mathrm{M}$ website views per year

At BMC, research is always in progress.

Learn more biomedcentral.com/submissions 